\title{
CHLOROFORM EXTRACTION OF TRACE NUTRIENTS AS OXINATES FROM SOIL EXTRACTS FOR SPECTROGRAPHIC ANALYSIS
}

\author{
Osmo MÄKITIE \\ Department of Soil Science, Agricultural Research Centre, Helsinki
}

Received August 24, 1960

When easily soluble trace elements in soils are to be analysed in soil extracts, a preliminary separation is necessary, as well as concentration of these trace constituents. 8-quinolinol is suitable for forming complexes, not only for precipitation, but also so that separations can be carried out by a simple chloroform extraction of metal complexes direct from the soil extract, using an exact acidity and a known concentration of reagent. The procedure also simplifies the actual quantitative spectrographic analysis and increases the accuracy of determinations sufficiently.

In this connection the suitability of 8-quinolinol for this separation has been investigated experimentally, in cases when the most important trace metals for plant nutrition, ie., cobalt, copper, manganese, molybdenum and zinc, are to be determined as trace nutrients by the usual soil testing method with acid ammonium acetate solution.

Mitchell and ScotT $(13,8)$ have achieved the pioneer work in this field, using 8-quinolinol, both alone and with some other reagents for precipitation of certain trace elements in soil analysis. Extraction procedures with oxinates and organic solvents have, however, not been presented earlier, although solvent extraction methods have been used in concentrating the trace elements from soil extracts, e.g., by dithizone extraction (14).

The purpose of the method is to separate the interesting trace metals as oxinates into the chloroform layer, together with the aluminum and iron also present in soil extracts. Alkalies and alkaline earths, which are the major constituents in these extracts, remain almost completely in the aqueous layer. Soil extracts contain calcium in the first place and it is very necessary to eliminate this for the purpose of spectrographic analysis. When the final spectrographic determinations are taken into consideration it is most desirable to collect and separate the trace metals with aluminum, which should be added to the solution in order to provide a spectrographic matrix in this way (11). 
Most of the metal oxinates dissolve well in chloroform and these complexes can be extracted completely from aqueous solution of a certain acidity (e.g. 5). The distribution of such oxinates has been more closely investigated in the case of only certain metals $(6,1)$. The oxinates of alkaline earths do not dissolve in chloroform, when a sufficiently dilute reagent concentration is used, e.g. $1 \% 8$-quinolinol in chloroform.

The hydrogen ion concentration and the concentration of the reagent both have an effect on the extraction, as reactive oxinate ion concentration in aqueous phase. Some earlier observations on the extractability are very contradictorary. The observations made by MoEller shall however be mentioned $(9,10)$. In this case, when a $0.01 \mathrm{M}$ oxine concentration was used with several successive extractions, the following elements were completely extracted; $\mathrm{Co}$ at $\mathrm{pH}$ over $6.8, \mathrm{Cu}$ at $\mathrm{pH} 2.0-$ 7.0, $\mathrm{Al}$ at $\mathrm{pH} 4.3-4.6$ and $\mathrm{Fe}(\mathrm{III})$ at $\mathrm{pH} 1.9-3.0$. Gentry and Sherrington $(2,3)$ have reported observations with $0.07 \mathrm{M}$ (equiv. $1 \%$ ) solutions, and with only one extraction; $\mathrm{Cu}$ at $\mathrm{pH} 2.8-14.0, \mathrm{Mn}$ at $\mathrm{pH} 7.2-$ c. 12.5, Mo at $\mathrm{pH} 1.6-5.6, \mathrm{Al}$ at $\mathrm{pH} 4.5-6.5$ and $8.0-11.5, \mathrm{Fe}$ at $\mathrm{pH} 2.5-12.5$. It is reported that zinc is incompletely extracted in the pH-range $4.6-13.4$ (12).

\section{Experimental}

Extraction method: The pre-treated soil sample is leached by shaking mechanically with acid ammonium acetate solution $\left(0.5 \mathrm{~N} \mathrm{CH}_{3} \mathrm{COOH}, 0.5 \mathrm{~N} \mathrm{CH}_{3} \mathrm{COONH}_{4}, \mathrm{pH} 4.65\right)$ for one hour, using a shaking ratio of $1: 10$ between the soil and solution (15). $100 \mathrm{ml}$ of filtered solution is evaporated in a beaker on a water bath to about half its volume, $5 \mathrm{ml}$ aluminum sulphate solution is added (equiv. $10 \mathrm{~g} \mathrm{Al}_{2} \mathrm{O}_{3}$ ), and a few drops of bromthymolblue are used as indicator. The solution is neutralized with ammonium hydroxide solution (1:2.5) to $\mathrm{pH} 6.2$ (or to a clear, greenish colour). It is then transferred into a $130 \mathrm{ml}$ separatory funnel, and shaken mechanically for five minutes with $10 \mathrm{ml}$ chloroform solution containing $1 \%$ oxine. After standing half an hour the chloroform is separated. Extraction is repeated with $5 \mathrm{ml}$ chloroform solution. The chloroform solutions are dried with sodium sulphate and evaporated to dryness in a small quartz crucible. The residue is ashed in a muffle furnace $\left(450^{\circ} \mathrm{C}\right)$ and the ash is then weighed for calculations and prepared into the crater of graphite electrodes for spectrographic excitation.

Spectrographic analysis: The analyses are carried out using a 2-m ARL grating spectrograph, according to the method published earlier $(11,7)$. The residue of oxinate ash which is collected with aluminum, is mixed with a 2.5 -fold lot of graphite powder, containing $250 \mathrm{ppm}$ silver and $50 \mathrm{ppm}$ palladium as internal standards. Silver acts as a standard element for volatile elements like zinc and copper, and palladium acts correspondingly for the less volatile ones such as manganese, molybdenum and cobalt. J.M. 4B graphite rods are used as electrodes, having a diameter of $6.5 \mathrm{~mm}$, a crater diameter of $2 \mathrm{~mm}$ and a depth of $3 \mathrm{~mm}$. For the first mentioned element group a D.C. arc of $9 \mathrm{~A}, 320 \mathrm{~V}$ with a capacitance of $40 \mu \mathrm{F}$ and a resistance of $25 \mathrm{ohms}$ is used, and correspondingly an excitation arc of $12 \mathrm{~A}$ is employed for the group of less volatile elements. An exposure time of 60 seconds with a slit of 40 microns is taken.

The films are calibrated by the method where known iron line intensities are measured to obtain the gamma-curve of the Kodak SA 1 film used. The analytical linepairs are: Cu 3273.96 $\AA$ and $\mathrm{Zn} 3345.02$ $\AA$ with $\mathrm{Ag} 3280.68 \AA$, and $C o 3453.51 \AA, M n 4034.49 \AA$ and Mo $3170.35 \AA$ with $\mathrm{Pd} 3421.24 \AA$. The intensity ratios of line pairs found by microphotometer are compared with the concentration working eurves, determined experimentally. In this way the concentration of the trace element in oxinate ash is determined and the figures for the soil are calculated from the weight of the ash. 
The extractability of the investigated trace metals from acetate solutions into chloroform is shown in Fig. 1. The concentrations commonly found in soils were used in these experiments (Co, Cu, Mo $0.1 \gamma / \mathrm{ml}, \mathrm{Zn} 0.3 \gamma / \mathrm{ml}$ and $\mathrm{Mn} 1 \gamma / \mathrm{ml}$ ). Fig. 1 presents parallel curves for the extractability of trace metals both from "pure" acetate solutions and from an extract made by shaking a typical, arable heavy clay soil with ammonium acetate solution.

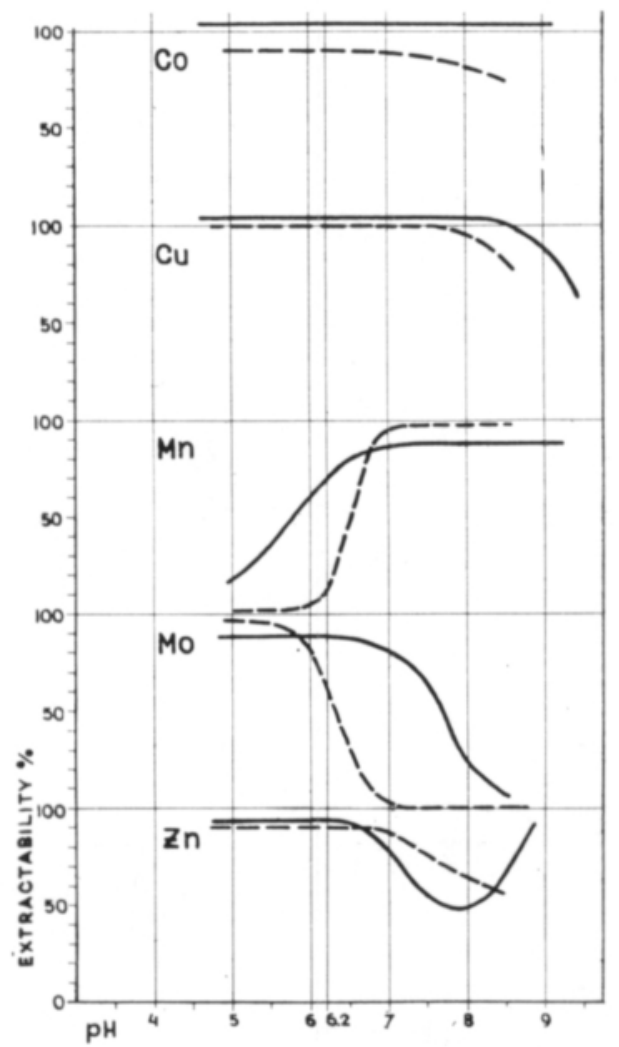

Fig. 1. The effect of $\mathrm{pH}$ on the extractability of oxinates in acetate solution in soil extract (continuousline) and in pure solutions (dotted-line).

The extractability of oxinates by a $1 \%$ oxine concentration is shown to happen in wider $\mathrm{pH}$ range in soil extracts than in pure acetate solutions, and also in some degree in a wider range than earlier reported observations have shown. This is probably caused by the character of the soil extract itself, by its ability to form chelates with the groupings of soil organic matter compounds (4). Especially it is shown in Fig. 1. in the manganese and molybdenum curves, and it also occurs in cobalt and copper extractions. The extractability of copper, manganese and molybdenum from acetate solutions correspond well with other observations made with the 
same reagent concentration (2). Earlier observations concerning cobalt and zinc are not available. Zinc can only be extracted inaccurately from neutral and alkaline solutions, which is probably because of the formation of hydroxide precipitate in the intersurface of the two phases.

The acidity itself is not decisive alone, as the concentration of the reagent, i.e. the oxine in the aqueous phase also has an effect on the course of the extraction. Fig. 2. shows the extraction rates of cobalt, manganese and molybdenum from ammonium acetate solutions. The extractions were carried out with $2 \times 10 \mathrm{ml}$ volumes of $0.1-3.0 \%$ oxine in chloroform, using the same element concentrations.

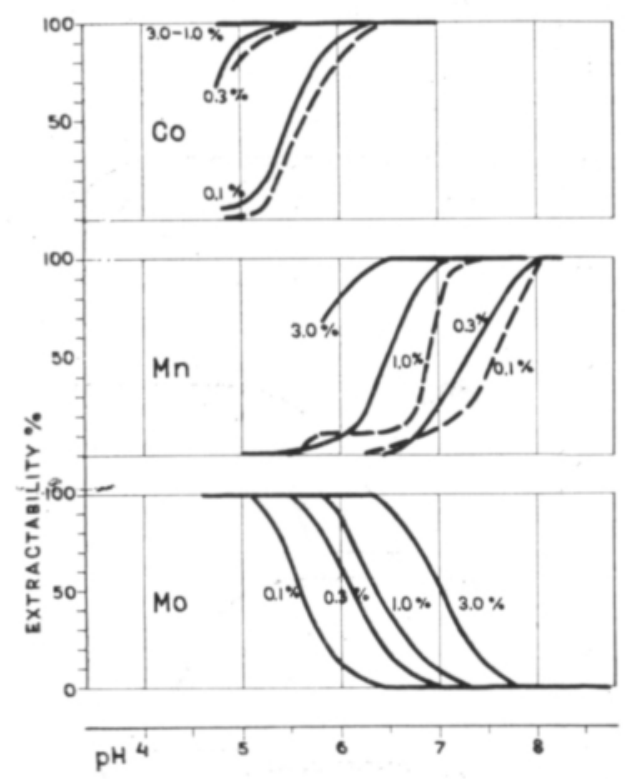

Fig. 2. The effect of oxine concentration on extraction. The dotted-line curves show the extraction in pure solutions.

Observations showed that the copper and zinc extractions were complete in the $\mathrm{pH}$-range investigated, even with the lowest concentration of the reagent. Cobalt was extracted with $1 \%$ oxine solution only when the $\mathrm{pH}$ was over 6 . Manganese can be extracted with $1 \%$ reagent only with a $\mathrm{pH}$ of over 7 , as has been shown earlier (12), while with $3 \%$ reagent, extraction occurs even in acid solution. The molybdenum curves are likewise separated evenly, showing that the stronger the concentration of the reagent, the nearer to neutral the extractability ceases.

The separation of trace nutrient metals as oxinates from a soil extract is possible both by precipitation, and by extraction. However extraction is the more profitable procedure when a number of routine analyses are to be carried out.

The extraction of the trace elements examined in this connection is sufficiently complete in the conditions of the procedure described above. The acidity of the solution, $\mathrm{pH} 6.2$, is selected to cover the simultaneous extraction of all these metals. 
The choice is not quite satisfactory however when the manganese extraction is not carried out at the most suitable acidity. To avoid this, the extraction can probably be done in two different stages, first separating the cobalt, copper, zinc and molybdenum at the proper acidity, $\mathrm{pH} 4.65$, and afterwards extracting the manganese from neutral solution. The advantage of this modification would be to increase the formation and extraction of aluminum and zinc oxinates in acid solution already, where precipitation would not yet occur.

The elimination of iron is desirable because soil extracts contain iron in different amounts, which disturbes the spectrographic analysis. Iron can also be prevented from taking part in the reaction by masking.

With regard to the spectrographic analysis it would be better to add the internal standards, silver and palladium to the solution before the proper extraction, presuming that these elements are also extracted as completely as the elements to be determined.

\section{$S u m$ m ary}

The experiments show that under these conditions the common trace nutrients, cobalt, copper, manganese, molybdenum and zinc are sufficiently completely extracted as chelates by shaking the soil extract with oxine-chloroform solution.

The hydrogen ion concentration of the extract and the concentration of oxine in chloroform have decisive effects on the extractability.

Using the reported and discussed procedure it is possible to separate the common trace metals from the major soil extract constituents, especially for spectrographic analysis.

R E F E R E N C E :

(1) Dyrssen, D. \& Dahlberg, V. 1953. Studies on the extraction of metal complexes. VIII: The extraction of La, Sm, Hf. Th and U (VI) with oxine and cupferron. Acta chem. scand. 7: $1186-1196$.

(2) Gentry, C. H. R. \& Sherrington, L. G. 1946. The direct photometric determination of Al with 8- hydroxyquinoline. Analyst 71: 432-438.

(3) Gentry, C. H. R. \& Sherrington, L. G. 1950. Extraction and photometric estimation of some metals with 8-hydroxyquinoline. Ibid. $75: 17-21$.

(4) Himes, F. L. \& Barber, S. A. 1957. Chelating ability of soil organic matter. Soil Sci. Soc. Amer. Proc. 21: $368-372$.

(5) Hollingshend, R. G. W. 1954. Oxine and its derivatives I-II, London (1954).

(6) Lacroix, S. 1947. Propriétés des oxinates d'aluminium, de gallium et d'indium. Séparation du gallium par extraction par le chloroforme. Anal. chem. acta 1: 260-290.

(7) LAPPI, L. \& MÄкıтıE, O. 1955. Quantitative spectrographic determination of minor elements in soil samples. Acta agric. scand. 5: $69-75$.

(8) Mrtchell, R. L. \& ScotT, R. O. 1947. Concentration methods in spectrographic analysis. II. Recovery of trace constituents in plant materials and soil extracts by mixed organic reagents. J. Soc. Chem. Ind. 66: $330-336$. 
(9) Moeller, P. 1943. The chemistry of indium. A colorimetric method for the estimation of small amount of indium. Ind. Eng. Chem., Anal. Ed. 15: 270-272.

(10) - 1943. Extraction and colorimetric estimation of certain metals as derivatives of 8-hydroxyquinoline. Ibid. $346-349$.

(11) Mäкıтіе, O. \& LAPPI, L. 1958. On the effect of matrix composition on the spectrochemical analysis of soil and plant ashes. Agrogeol. publ. No 68. pp. 36.

(12) Sandell, E. B. 1950. Colorimetric determination of traces of metals. New York.

(13) Scott, R. O. \& MrтенеLl, R. L. 1943. Concentration methods in spectrographic analysis. I: Recovery of $\mathrm{Co}, \mathrm{Ni}, \mathrm{Mo}, \mathrm{Cu}, \mathrm{Zn}$ from plant materials and soil extracts by 8 -hydroxyquinoline. J. Soc. Chem. Ind. 62: 4-13.

(14) WARK, W. J. 1954. Spectrographic analysis of minor elements extracted from plants and soils as dithizonates. Anal. Chem. 26: 203-205.

(15) Vuorinen, J. \& Mäкitie, O. 1955. The method of soil testing in use in Finland. Agrogeol. publ. No. 63. pp. 44.

S E L OS T U S:

\section{MAAUUTTEEN HIVENRAVINTEIDEN KLOROFORMIEKSTRAKTIOSTA OKSINAATTEINA SPEKTROGRAAFISTA ANALYYSIA VARTEN}

\section{Osmo MÄкITIE}

Maantutkimuslaitos, Maatalouden tutkimuskeskus, Helsinki

Tutkimuksessa on kokeellisesti selvitetty oksiinin käyttöä maan helppoliukoisten hivenravinteiden, nimenomaan koboltin, kuparin, mangaanin, molybdeenin ja sinkin erottamiseksi kloroformiin spektrograafista analyysia varten.

Kelaattien ekstraktioon vaikuttavat ensi sijassa uuteliuoksen happamuus ja oksiiniväkevyys kloroformissa.

Esitetyllä menetelmällä voidaan mainitut hivenaineet erottaa uutteen pääaineksista ja rikastaa riittävän täydellisesti tarkoituksenmukaista spektraalianalyysia varten. 